\title{
Pertanggungjawaban Hukum Pejabat Pembina Kepegawaian dan Pejabat yang Berwenang atas Kesalahan dalam Penjatuhan Hukuman Disiplin Pegawai Negeri Sipil
}

\author{
Rony Alfredo Rumapea \\ Program Magister Ilmu Hukum Universitas Padjadjaran, Bandung, Indonesia \\ E-mail:alfredoderumapea@gmail.com
}

\begin{abstract}
Law enforcement is an effort to build legal ideas and concepts that are expected by the people to become a reality. Supervision and the imposition of the right sanctions for indisiplinary and code of ethics violations is needed in the context of law enforcement. The law firmly states that government officers are dishonorably discharged because they are convicted of a criminal offense or criminal offense that has to do with office and / or general crime, including acts of corruption. It is necessary to review the application of appropriate principles and norms to fulfill the accountability of officials who do not use their authority to impose sanctions for violations committed by public servants. We must examine and review various regulations relating using a normative juridical approach to find out how these regulations are implemented in administrative law enforcement. Administrative and criminal legal liability in the form of sanctions must be imposed on the Chief Officer / Authorized Officer.
\end{abstract}

Keywords: Law; Governance; Law Enforcements; Administrative Law; Corruption.

\section{A. PENDAHULUAN}

Berdasarkan data yang dipublikasikan oleh Kementerian Hukum dan HAM, terdapat 1879 PNS yang menjadi terpidana dengan berbagai jenis pelanggaran hukum selama kurun waktu tahun 2014 sampai dengan tahun 2017. ${ }^{1}$ Jika diklasifikasi berdasarkan jenis pelanggaran, tindak pidana korupsi berada di posisi tertinggi dengan jumlah mencapai 1087 kasus.

Dalam rilis lain yang dipublikasikan oleh Badan Kepegawaian Negara (BKN) menyebutkan bahwa terdapat 2.674 PNS pernah terlibat korupsi. Dari jumlah tersebut hanya 11,9\% atau setara dengan 317 pegawai yang sudah diberhentikan, sementara 85,1\% atau 2674 pegawai lain masih berstatus aktif sebagai pegawai. Persentase ini menunjukkan masih lemahnya komitmen birokrat dalam penegakan kode etik dan kode perilaku melalui hukuman berat bagi para pelanggar. ${ }^{2}$

1 Mokhsen, Nuraida dkk. (2019), Pengawasan Penegakan Kode Etik dan Kode Perilaku Pegawai Aparatur Sipil Negara, Jurnal Komisi Aparatur Sipil Negara, Edisi Kedua, h. 1

${ }^{2}$ Ibid. h. 2 
Berdasarkan aturan yang berlaku, para PNS yang sudah menjadi terpidana korupsi seharusnya dikenakan sanksi administratif dengan kategori hukuman disiplin berat berupa Pemberhentian Tidak Dengan Hormat (PTDH). Menurut data dari BKN yang menyebutkan hingga kini masih banyak terpidana korupsi yang kembali aktif bekerja sebagai PNS setelah menjalani hukuman pidananya maka pemerintah meningkatkan sinergi dengan mengeluarkan Surat Keputusan Bersama (SKB) untuk memberhentikan secara tidak hormat Pegawai Negeri Sipil (PNS) pelaku tindak pidana korupsi (tipikor) yang berstatus inkracht. ${ }^{3}$

Surat Keputusan Bersama tersebut telah ditandatangani pada 13 September 2018 Kesepakatan itu dituangkan dalam Keputusan Bersama (SKB) Mendagri, Menteri PANRB, dan Kepala BKN tentang Penegakan Hukum Terhadap PNS Yang Telah Dijatuhi Hukuman Berdasarkan Putusan Pengadilan Yang Berkekuatan Hukum Tetap Karena Melakukan Tindak Pidana Jabatan atau Tindak Pidana Kejahatan Yang Ada Hubungannya dengan Jabatan. SKB tersebut terbit tanggal 13 September 2018, dengan Nomor 182/6597/SJ, Nomor 15 Tahun 2018, dan Nomor 153/KEP/2018.

SKB tersebut memuat perintah kepada seluruh Pejabat Pembina Kepegawaian (PPK) dan Pejabat Yang Berwenang (PYB) di instansi pusat dan daerah untuk melakukan penjatuhan sanksi kepada PNS Terpidana Korupsi berupa pemberhentian tidak dengan hormat sebagai PNS. Selain itu, juga terdapat ancaman penjatuhan sanksi kepada PPK dan PYB yang tidak melakukan perintah SKB tersebut. Jumlah penyelesaian kasus PNS Tipikor BHT sebanyak 1.906 PNS dari total 2.357 sudah ditetapkan SK PTDH, dengan rincian sebagai berikut: ${ }^{4}$

Tabel 1.

Penyelesaian Kasus PNS Tipikor BHT dan sudah ditetapkan SK PTDH

\begin{tabular}{lcc}
\hline \multicolumn{1}{c}{ Instansi } & $\begin{array}{c}\text { Jumlah PNS Tipikor } \\
\text { BHT (orang) }\end{array}$ & $\begin{array}{c}\text { SK PTDH } \\
\text { DITETAPKAN }\end{array}$ \\
\hline Instansi Pusat & 98 & 84 \\
\hline Instansi Daerah & 2.259 & 1.822 \\
\hline Total & $\mathbf{2 . 3 5 7}$ & $\mathbf{1 . 9 0 6}$ \\
\hline
\end{tabular}

Berdasarkan penjelasan di atas, maka kita ketahui bahwa ternyata banyak PNS terpidana korupsi yang tidak dijatuhi hukuman disiplin sesuai aturan oleh PPK dan PYB. Pasca diterbitkannya SKB tersebut, terjadi pemberhentian PNS secara besar-besaran. Namun terdapat poin penting yang menimbulkan pertanyaan yaitu tidak adanya tindakan pemerintah pusat untuk menuntut pertanggungjawaban kepada PPK dan PYB terdahulu yang tidak menjatuhkan sanksi PTDH sebelum SKB tersebut terbit.

\footnotetext{
3 Sekretariat Kabinet. (2019). Keputusan Bersama Dirilis PNS Koruptor Akan Dipecat Desember 2018. Tersedia di https://tirto.id/keputusan-bersama-dirilis-pns-koruptor-akan-dipecat-desember- 2018cZk1 (diakses 19 Agustus 2019)

4 Sekretariat Kabinet. (2019). Penuntasan Capai 88\%, 1.906 PNS Terlibat Tipikor Diberhentikan Tidak Hormat, Tersedia di https://setkab.go.id/penuntasan-capai-88-1-906-pns-terlibat-tipikordiberhentikan-tidak- hormat/ (diakses 13 Agustus 2019)
} 
Selama ini telah banyak tulisan yang membahas mengenai penegakan hukum terhadap para PNS yang melanggar aturan dan meninjau kepastian hukum serta keadilan terkait pemecatan PNS Terpidana Korupsi. Namun sejauh ini belum ada yang membahas pertanggungjawaban para Pejabat Pembina Kepegawaian/Pejabat yang Berwenang yang tidak menjalankan kewenangannya sesuai aturan. Terhadap permasalahan tersebut maka penulis berpendapat seharusnya ada pertanggungjawaban hukum yang dilakukan oleh para PPK/PYB terkait untuk mewujudkan tujuan dari Undang-Undang Nomor 30 Tahun 2014 tentang Administrasi Pemerintahan yang disebutkan dalam pasal 3 yaitu menciptakan tertib penyelenggaraan Administrasi Pemerintahan, menciptakan kepastian hukum, mencegah terjadinya penyalahgunaan Wewenang dan menjamin akuntabilitas Badan dan/atau Pejabat Pemerintahan.

\section{B. METODE PENELITIAN}

Metode penelitian yang digunakan berupa pendekatan yuridis normatif. Pendekatan ini dilakukan dengan cara meneliti bahan kepustakaan atau data sekunder yang dapat menjadi referensi penelitian hukum. Oleh karena itu data yang dipergunakan adalah data yang diperoleh dari hasil penelitian dan kajian bahan-bahan pustaka. Pendekatan yuridis normatif digunakan dengan pertimbangan bahwa penelitian ini bertujuan untuk membahas dan mengkaji berbagai peraturan yang berkaitan dengan peraturan keparaturan negara dan yuridis normatif untuk mengetahui bagaimana peraturan tersebut diimplementasikan dalam penegakan hukum administratif.

Penelitian ini akan dilakukan dengan spesifikasi bersifat deskriptif analitis yang membahas mengenai implementasi dan menguji pelaksanaan ketentuan normatif di dalam praktek. Deskriptif berarti bersifat menggambarkan kondisi pelaksanaan administrasi pemerintahan di lapangan. Suatu penelitian deskriptif dimaksudkan untuk memberikan data seteliti mungkin tentang manusia, keadaan atau gejala-gejala lainnya. ${ }^{5}$ Kemudian dianalisis berdasarkan teori-teori dan peraturan perundang-undangan yang digunakan sebagai bahan-bahan hukum dalam penelitian ini

\section{PEMBAHASAN}

\section{Penegakan Hukum Disiplin Pegawai}

Menurut Penjelasan Undang-undang Dasar 1945, Negara Republik Indonesia adalah negara yang berdasar atas hukum (rechtsstaat), tidak berdasarkan kekuasaan belaka (machtsstaat). Hal ini juga dinyatakan dalam Ketentuan Pasal 1 ayat (3) UUD 1945 Amandemen Ke-IV yang menetapkan bahwa Negara Indonesia adalah negara hukum. Pernyataan dalam ketentuan Pasal 1 ayat (3) ini menunjukkan bahwa dalam menjalankan proses bernegara dan penyelenggaraan pemerintahan, baik itu mencakup antara lain lembaga negara eksekutif, lembaga legislatif dan lembaga yudikatif harus diijalankan sesuai dengan sistem hukum yang berlaku di Indonesia.

Tujuan negara adalah untuk memelihara ketertiban hukum (rectsorde). Oleh karena itu, negara membutuhkan keberadaaan hukum dan sebaliknya pula hukum harus dapat dijalankan dan ditegakkan oleh otoritas negara. ${ }^{6}$ Aristoteles menegaskan bahwa sumber kekuasaan adalah hukum yang tidak hanya memiliki kedaulatan dan kewibawaan yang tertinggi tetapi juga harus dijadikan sebagai dasar dan landasan kehidupan bernegara. Ini

\footnotetext{
5 Soekanto, Soerjono. (2008). Pengantar Penelitian Hukum, Jakarta: UI Press, h.1

${ }^{6}$ Gautama, Sudargo. (1973). Pengertian Negara Hukum, Bandung : Alumni, h. 20
} 
berlaku bagi yang memerintah maupun diperintah sehingga kedua belah pihak sama-sama berada pada kedudukan hukum yang sejajar.

Apabila hukum yang menjadi sumber kekuasaan, maka jelas bahwa para penguasa akan menaklukkan diri di bawah hukum. Hukum akan menciptakan para penguasa negara yang memiliki moralitas terpuji dan keadaban yang tinggi dan dengan begitu kesewenangan tidak akan terjadi sehingga tercipta ketentraman dan ketertiban dalam masyarakat. $^{7}$

Dalam konteks birokrasi maka penegakan hukum berarti bahwa seluruh pejabat dan pegawai pemerintahan (aparatur sipil negara) harus menjalankan ketentuan- ketentuan normatif yang sudah ditetapkan dan melakukan kewajiban atau tidak melakukan sesuatu yang dilarang oleh peraturan perundangan-undangan yang berlaku. Untuk mendukung penegakan hukum tersebut dibutuhkan sarana penegakan hukum yang sesuai dengan bidang administrasi kepegawaian.

Menurut P. Nicolai dan kawan-kawan, terdapat dua instrumen penegakan hukum Administrasi Negara yaitu ${ }^{8}$ :

a) Pengawasan terhadap organ pemerintahan dalam rangka memastikan ketaatan pada undang-undang yang ditetapkan secara tertulis dan pengawasan terhadap keputusan yang memberikan suatu kewajiban kepada individu.

b) Penerapan kewenangan sanksi pemerintahan.

Pengawasan dan penjatuhan sanksi atas pelanggaran sangat diperlukan dalam upaya penegakan disiplin pegawai. Pejabat memiliki hak dan kewajiban dalam pelaksanaan kewenangan untuk mengambil Keputusan dan/atau Tindakan sesuai ketentuan dalam Bab IV, pasal 6 Undang Undang Nomor 30 Tahun 2014 Tentang Administrasi Pemerintahan.

Berdasarkan Undang Undang Nomor 5 tahun 2014 Tentang Aparatur Sipil Negara jo. Peraturan Pemerintah Nomor 11 Tahun 2017 Tentang Manajemen Pegawai Negeri Sipil yang disebut sebagai PPK dan PYB adalah:

a) Pejabat Pembina Kepegawaian (PPK) adalah pejabat yang mempunyai kewenangan menetapkan pengangkatan, pemindahan, dan pemberhentian Pegawai ASN dan pembinaan manajemen ASN di instansi pemerintah sesuai dengan ketentuan peraturan perundang-undangan. Presiden adalah pemegang kekuasaan tertinggi pembinaan PNS yang dapat mendelegasikan kewenangannya kepada Menteri, pimpinan lembaga pemerintah nonkementerian, sekretaris jenderal di sekretariat lembaga negara dan lembaga nonstructural, gubernur, dan bupati/walikota.

b) Pejabat Yang Berwenang (PYB) adalah pejabat yang mempunyai kewenangan melaksanakan proses pengangkatan, pemindahan, dan pemberhentian Pegawai ASN sesuai dengan ketentuan peraturan perundang-undangan. Presiden dapat mendelegasikan kewenangan pembinaan Manajemen ASN kepada Pejabat yang Berwenang di Kementerian dan Lembaga yaitu sekretaris jenderal, sekretariat lembaga Negara, sekretariat lembaga nonstructural, dan sekretaris daerah provinsi/kabupaten/kota.

Berdasarkan hasil pengawasan dan evaluasi oleh Komisi Aparatur Sipil Negara pada beberapa instansi pemerintah khususnya di daerah, terdapat 7 (tujuh) hal yang menjadi penyebab PPK yang tidak segera melakukan PTDH terhadap PNS Terpidana

\footnotetext{
${ }^{7}$ Rapar, J. H. (1993). Filsafat Politik Aristoteles. Jakarta: CV. Rajawali.

8 Anggara, Sahya. (2018) Hukum Administrasi Negara, Bandung: CV Pustaka Setia, h 133
} 
Korupsi yaitu sebagai berikut: ${ }^{9}$

a) Terjadinya Konflik Kepentingan

b) Ketakutan adanya Tuntutan Ganti Rugi

c) Belum Memperoleh Putusan Pengadilan

d) Menunggu Hasil Uji Materi Mahkamah Konstitusi (MK)

e) Keengganan Berurusan dengan PTUN

f) Rasa Kasihan dan Kemanusiaan

g) PNS Terpidana Korupsi Pindahan dari Instansi Lain

Dalam Pasal 87 ayat (4b) Undang-Undang Nomor 5 Tahun 2014 tentang Aparatur Sipil Negara (ASN) ditegaskan beberapa hal yaitu:

1) PNS diberhentikan tidak dengan hormat karena dihukum penjara atau kurungan berdasarkan putusan pengadilan yang telah memiliki kekuatan hukum tetap;

2) karena melakukan tindak pidana kejahatan atau tindak pidana kejahatan yang ada hubungannya dengan jabatan dan/atau pidana umum, termasuk tindakan pidana korupsi.

Aturan yang jelas dan tegas seperti ini maka seharusnya tidak membuka ruang penerapan diskresi oleh PPK/PYB dalam penjatuhan sanksi PTDH terhadap PNS yang telah menjadi terpidana korupsi. Hal ini dapat dianggap sebagai penyalahgunaan wewenang seperti yang dilarang dalam pasal 18 Undang Undang Nomor 30 Tahun 2014 Tentang Administrasi Pemerintahan. Wewenang dalam perspektif hukum berupa hak dan kewajiban (rechten en plichten). Badan dan/atau Pejabat Pemerintahan dikategorikan melampaui wewenang apabila Keputusan dan/atau Tindakan yang dilakukan bertentangan dengan hak dan kewajiban yang diatur dalam peraturan perundangundangan.

Pejabat yang tidak melakukan kewenangannya untuk menjatuhkan sanksi terhadap pelanggaran yang dilakukan oleh PNS juga menjadi bukti bahwa penegakan hukum administrasi di bidang kepegawaian masih sangat lemah. PPK dan PYB merupakan individu yang seharusnya terlibat langsung dalam rangkaian proses penegakan hukum di ranah administrasi pemerintahan. Ini sekaligus menjadi bukti bahwa ketaatan hukum para Pejabat masih rendah dan pengawasan oleh Pemerintah Pusat terhadap para pejabat tersebut juga masih tidak efektif. Hal ini tentu saja tidak sesuai dengan nilai-nilai keadilan yang terdapat dalam masyarakat

\section{Pertanggungjawaban Hukum Pejabat Pembina Kepegawaian dan Pejabat Yang Berwenang Atas Kesalahan Dalam Penjatuhan Hukuman Disiplin PNS}

Berdasarkan data yang telah diberikan menunjukkan PPK/PYB yang berwenang menjatuhkan sanksi banyak yang tidak melaksanakan wewenangnya secara tepat. Ketentuan untuk menjalankan wewenang tersebut sudah sangat jelas dan tegas disebutkan dalam Undang-Undang Nomor 5 Tahun 2014 tentang Aparatur Sipil Negara, dan Peraturan Pemerintah Nomor 11 Tahun 2017 tentang Manajemen Pegawai Negeri Sipil.

Maka dapat dikatakan bahwa terdapat pelanggaran oleh para PPK/PYB terhadap peraturan perundang-undangan terkait. Kelemahan dalam penegakan hukum terhadap PNS yang sudah menjadi terpidana korupsi menyebabkan beberapa permasalahan salah

9 Komisi Aparatur Sipil Negara. (2019) 7 Alasan PPK belum melakukan PTDH Terhadap ASN Berstatus Terpidana Korupsi, Tersedia di https://www.kasn.go.id/details/item/368-7- alasan-ppk-belummelakukan-ptdh-terhadap-asn-berstatus-terpidana-korupsi. (diakses 13 Agustus 2019). 
satunya dalam keuangan negara. PNS Terpidana Korupsi masih menerima sebagian penghasilan dari negara selama menjalani hukuman penjara dan penghasilan penuh setelah kembali menempati jabatan sampai saat ini.

Selain daripada itu, PNS terpidana korupsi juga masih menerima penghasilan dari negara sampai pensiun karena PNS yang bersangkutan masih belum dipecat. Padahal PNS yang bersangkutan seharusnya telah diberhentikan sejak terbitnya putusan pengadilan berkekuatan hukum tetap. Pemberhentian sebagai PNS adalah pemberhentian yang mengakibatkan yang bersangkutan tidak lagi berkedudukan sebagai PNS. Namun jika PNS diberhentikan secara tidak dengan hormat maka yang bersangkutan akan kehilangan salah satu hak kepegawaiannya yaitu, hak atas jaminan pensiun. ${ }^{10}$ Ini menyebabkan PNS Terpidana Korupsi masih menerima hak pensiunnya karena tidak dipecat sebelum pensiun.

Berdasarkan perhitungan Indonesia Corruption Watch (ICW), terdapat potensi kerugian negara setiap tahun lantaran menggaji PNS terpidana korupsi. PNS yang menjadi terpidana korupsi itu masih menerima penghasilan selama dipenjara dan setelah kembali bekerja dengan rata-rata gaji pokok sebesar Rp 3,5 juta. ${ }^{11}$ Ini menimbulkan ketidakpercayaan dari masyarakat terhadap integritas pejabat dalam pengelolaan keuangan negara dan menggambarkan pelaksanaan administrasi negara oleh pejabat yang kurang profesional dan tidak taat hukum. Oleh karena itu untuk meningkatkan kepercayaan publik maka perlu ada pertanggungjawaban hukum dari para PPK/PYB atas keputusannya yang tidak sesuai aturan.

Pertanggungjawaban berasal dari kata tanggung jawab, yang berarti keadaan wajib menanggung segala dampak yang diakibatkan dari sesuatu hal yang dilakukan yang menjadikannya boleh dituntut, dipersalahkan, diperkarakan, dan sebagainya. ${ }^{12}$ Tanggung jawab dalam kamus hukum dapat disebut sebagai liability dan responsibility. Istilah liability menunjuk pada pertanggungjawaban hukum yaitu tanggung gugat akibat kesalahan yang dilakukan oleh subjek hukum, sedangkan istilah responsibility menunjuk pada pertanggungjawaban yang bersifat politik. $^{13}$

Teori mengenai tanggung jawab lebih menekankan pada makna tanggung jawab yang lahir dari ketentuan Peraturan Perundang-Undangan sehingga teori tanggungjawab dimaknai dalam arti liabilty, sebagai suatu konsep yang terkait dengan kewajiban hukum seseorang yang bertanggung jawab secara hukum atas perbuatan tertentu bahwa dia dapat dikenakan suatu sanksi dalam kasus perbuatannya bertentangan dengan hukum. ${ }^{14}$

Memaknai pertanggungjawaban dalam administrasi pemerintahan, maka diskresi akan terkait dengan permasalahan subyek yang memiliki kewenangan untuk membuat keputusan. Dalam hal ini maka subyek yang berwenang untuk membuat suatu diskresi adalah pejabat pemerintahan. Dalam konteks penjatuhan hukuman disiplin, PPK/PYB yang memilih untuk tidak menjalankan kewenangan yang diamanatkan oleh undangundang seharusnya juga dapat dibebankan tanggung jawab. Konsep tanggung jawab dalam permasalahan pelaksanaan wewenang pejabat dapat diartikan sebagai tanggung

10 Muvariz, Fitri Rahmadhani (2019), Analisis Aspek Keadilan Dari Pemberhentian Tidak Dengan Hormat Sebagai Pegawai Negeri Sipil Di Indonesia, Jurnal Legislasi Indonesia Vol. 16 No.2 - Juni 2019, h. 198.

11 https://nasional .republika.co.id Berapa kerugian negara jika PNS korup belum dipecat. (diakses 9 September 2019)

12 Poerwadarminta, WJS. (1976), Kamus Umum Bahasa Indonesia, Jakarta, h. 1014.

13 HR, Ridwan (2006). Hukum Administrasi Negara, Jakarta: Raja Grafindo Persada, h. 337

14 Azheri, Busyra. (2011), Corporate Social Responsibility dari Voluntary menjadi Mandotary. Jakarta: RajaGrafindo Perss, h. 54. 
jawab dalam arti hukum yaitu yang benar-benar terkait dengan hak dan kewajibannya. Hal ini berkaitan dengan konsep negara hukum yang mensyaratkan adanya tanggungjawab pemerintah dimana ada kewajiban penguasa untuk mempertanggungjawabkan secara hukum penggunaan kekuasaan yang dapat menimbulkan kerugian bagi warganya. ${ }^{15}$

PPK/PYB merasa memiliki kebebasan melakukan interpretasi terhadap aturan yang ada sehingga menganggap memiliki hak untuk mengambil diskresi untuk tidak melakukan penjatuhan hukuman disiplin PTDH terhadap PNS terpidana korupsi. Namun apabila tindakan diskresi yang dilakukan melanggar aturan yang sudah jelas dan tegas maka individu Pejabat harus bertanggungjawab terhadap pelanggaran yang di lakukannya sendiri. Kesalahan yang terjadi bersifat subyektif yang motivasinya hanya dapat diketahui oleh individu yang bersangkutan kecuali ada motivasi yang dapat dibuktikan di pengadilan.

Berdasarkan prinsip "deen bevoegheid zonder verantwoordenlijkheid" dimana tidak ada satu kewenangan pun tanpa adanya pertanggungjawaban maka setiap penggunaan wewenang oleh pejabat selalu disertai dengan tuntutan tanggung jawab. ${ }^{16}$ Wewenang menjatuhkan sanksi melekat pada jabatan sebagai PPK/PYB yang diamanatkan kepada individu yang memangku jabatan tersebut. Pertanggungjawaban yang dapat dimintakan berupa tanggung jawab jabatan dan tanggung jawab pribadi dengan penjelasan sebagai berikut: ${ }^{17}$

1) Tanggung Jawab Jabatan

Pejabat hanya menjalankan fungsi dan wewenang yang diberikan oleh hukum karena secara individu pejabat tidak memiliki wewenang. Jabatannya lah yang memiliki dan dilekati wewenang.

2) Tanggung Jawab Pribadi

Tanggung jawab pribadi berkaitan dengan pelaksanaan wewenang dan layanan publik yang mengandung unsur maladministrasi. Seorang pejabat yang melaksanakan tugas dan kewenangan jabatan atau membuat kebijakan akan dibebani tanggung jawab pribadi jika terbukti melakukan tindakan maladministrasi. F.R.Bothlingk mengatakan bahwa pejabat atau wakil itu bertanggung jawab sepenuhnya, ketika ia menyalahgunakan situasi dengan melakukan tindakan amoralnya sendiri terhadap kepentingan pihak ketiga. ${ }^{18}$

\section{Proses Pemeriksaan Terhadap Penyalahgunaan Wewenang Oleh PPK/PYB Dalam Penjatuhan Hukuman Disiplin PNS}

Wewenang itu melekat pada jabatan, namun dalam implementasinya dijalankan oleh manusia selaku wakil atau fungsionaris jabatan, oleh karena itu siapa yang harus memikul tanggung jawab hukum ketika terjadi penyimpangan harus dilihat secara kasuistik karena tanggung jawab itu dapat berupa tanggung jawab jabatan dan dapat pula berupa tanggung jawab dan tanggung gugat pribadi. Dalam kasus penjatuhan hukuman

15 Mustamu, Julista. (2014) Pertanggungjawaban Hukum Pemerintah (Kajian Tentang Ruang Lingkup Dan Hubungan Dengan Diskresi). SASI Vol. 20 No. 2 Bulan Juli - Desember 2014, h. 21.

16 Johan, Teuku Saiful Bahri. (2018) Hukum Tata Negara dan Hukum Admnistrasi Negara dalam Tataran Reformasi Ketatanegaraan Indonesia, Yogyakarta: Deepublish, h. 195

17 Ibid. h. 195-196

18 Ibid. h. 142 
disiplin maka tanggung jawab jabatan dan tanggung jawab pribadi harus dibebankan kepada Pejabat Pembina Kepegawaian atau Pejabat Yang Berwenang. Pembebanan tersebut karena Pejabat yang bersangkutan secara jabatan memiliki hak dan kewajiban yang melekat dari wewenangnya untuk menjatuhkan hukuman disiplin berat, namun tidak melakukannya dengan adanya kemungkinan maladministrasi. Unsur maladministrasi ini yang menjadi syarat supaya dapat dibebankan pertanggungjawaban terhadap pribadi.

Maladministrasi dalam Undang-Undang Nomor 37 Tahun 2008 tentang Ombudsman Republik Indonesia diartikan sebagai perilaku atau perbuatan yang dilakukan oleh Penyelenggara Negara dan pemerintahan yang melawan hukum, melampaui wewenang, menggunakan wewenang untuk tujuan yang lain dari yang sudah ditentukan, termasuk kelalaian atau pengabaian kewajiban hukum dalam penyelenggaraan pelayanan publik yang menimbulkan kerugian materiil dan/atau immateriil bagi masyarakat dan orang perseorangan.

Menentukan adanya maladministrasi dalam penjatuhan hukuman disiplin maka diperlukan investigasi. Bentuk tindakan maladministrasi adalah tindakan-tindakan yang dilakukan aparatur pemerintah dikarenakan adanya korupsi yang terjadi karena penyalahgunaan wewenang yang dimilikinya, termasuk didalamnya mempergunakan kewenangan untuk tujuan lain dari tujuan pemberian kewenangan, dan dengan tindakan tersebut untuk kepentingan memperkaya dirinya, orang lain kelompok maupun korporasi yang merugikan keuangan negara. ${ }^{19}$ Apabila merujuk pada buku saku Ombudsman RI, bentuk maladministrasi yang terjadi dalam proses penjatuhan hukuman disiplin dapat juga berupa ${ }^{20}$ :

a) Mengabaikan hukum (disregard of law) yang termasuk didalamnya adalah tindakan menyepelekan hukum untuk kepentingan dirinya sendiri, atau kepentingan kelompoknya.

b) Favoritisme dalam menafsirkan hukum yaitu melakukan penafsiran hukum untuk kepentingan kelompoknya.

c) Perlakuan yang tidak adil terhadap pegawai, yang dilakukan oleh pimpinan kepada bawahannya cenderung berdasarkan faktor like and dislike.

Setelah diperoleh fakta dan bukti yang cukup dari hasil investigasi maka akan dapat ditentukan pertanggungjawaban yang harus dibebankan kepada PPK/PYB terkait. Berdasarkan Peraturan Pemerintah Nomor 48 Tahun 2016 Tentang Tata Cara Pengenaan Sanksi Administratif Kepada Pejabat Pemerintahan disebutkan bahwa Pejabat yang Berwenang memeriksa dugaan pelanggaran dan menjatuhkan sanksi administratif adalah sebagai berikut:

a) Pemeriksaan dan pengenaan sanksi terhadap Pejabat Pemerintahan yang diduga melakukan Pelanggaran Administratif ringan dilakukan oleh Atasan Pejabat atau dapat dilakukan oleh Tim Ad Hoc yang dibentuk Atasan Pejabat atau diserahkan kepada aparat pengawas internal pemerintah (APIP).

b) Jika dilakukan oleh pejabat daerah maka Pejabat yang berwenang memberi sanksi adalah kepala daerah berdasarkan hasil pemeriksaan internal oleh APIP.

c) Jika dilakukan oleh pejabat di lingkungan kementerian/lembaga maka Pejabat yang berwenang memberi sanksi adalah menteri/pimpinan lembaga berdasarkan hasil pemeriksaan APIP.

19 Nurtjahjo, Hendra dkk. (2013) Memahami Maladministrasi. Jakarta: Ombudsman Republik Indonesia. h. 12

${ }^{20}$ Ibid. h. 13-14 
d) Jika dilakukan oleh bupati/walikota maka Pejabat yang berwenang memberi sanksi adalah gubernur berdasarkan hasil pemeriksaan APIP provinsi/daerah.

e) Jika dilakukan oleh gubernur maka Pejabat yang berwenang memberi sanksi adalah menteri yang menyelenggarakan urusan pemerintahan dalam negeri berdasarkan hasil pemeriksaan APIP kementerian yang menyelenggarakan urusan pemerintahan dalam negeri .

f) Jika dilakukan oleh menteri/pimpinan lembaga maka Pejabat yang berwenang memberi sanksi adalah Presiden berdasarkan hasil pemeriksaan APIP yang ditunjuk oleh Presiden.

Pasal 33 PP Nomor 48 Tahun 2016 tersebut dijelaskan bahwa Hasil pemeriksaan dari APIP sebagaimana dimaksud dapat berupa tidak terdapat kesalahan, terdapat kesalahan administratif; atau terdapat kesalahan administratif yang menimbulkan kerugian keuangan negara.

Apabila terdapat kesalahan administratif yang menimbulkan kerugian keuangan negara maka pertanggungjawaban yang dibebankan menurut PP Nomor 48 Tahun 2016 adalah dengan melakukan pengembalian uang ke kas negara/daerah. Dijelaskan pula dalam pasal 34 bahwa apabila tidak terdapat unsur yang menunjukkan terjadinya penyalahgunaan wewenang oleh Pejabat, maka Badan yang diminta untuk melakukan pengembalian uang ke kas negara/daerah. Namun, apabila ada unsur penyalahgunaan wewenang oleh Pejabat, maka yang bertanggungjawab adalah Pejabat yang bersangkutan.

Menurut ketentuan Pasal 17 UU Nomor 30 Tahun 2014, badan dan/atau pejabat pemerintahan dilarang menyalahgunakan wewenang, larangan itu meliputi larangan melampaui wewenang, larangan mencampuradukkan wewenang, dan/atau larangan bertindak sewenang-wenang. Badan dan/atau pejabat pemerintahan dikategorikan melampaui wewenang apabila keputusan dan/atau tindakan yang dilakukan melampaui masa jabatan atau batas waktu berlakunya wewenang, melampaui batas wilayah berlakunya wewenang, dan/atau bertentangan dengan ketentuan peraturan perundangundangan.

Badan dan/atau pejabat pemerintahan dikategorikan mencampuradukkan wewenang apabila keputusan dan/atau tindakan yang dilakukan di luar cakupan bidang atau materi wewenang yang diberikan, dan/atau bertentangan dengan tujuan wewenang yang diberikan. Badan dan/atau pejabat pemerintahan dikategorikan bertindak sewenangwenang apabila keputusan dan/atau tindakan yang dilakukan tanpa dasar kewenangan, dan/atau bertentangan dengan putusan pengadilan yang berkekuatan hukum tetap.

Konteks penjatuhan hukuman disiplin maka PPK/PYB yang tidak menjatuhkan sanksi PTDH terhadap PNS Terpidana Korupsi dapat dikatakan telah bertentangan dengan ketentuan peraturan perundang-undangan. Untuk menguji terjadinya penyalahgunaan wewenang maka APIP harus melakukan klarifikasi dan validasi terhadap laporan pelanggaran dan kemudian mengumpulkan fakta, data, dan/atau keterangan lain. Sebagaimana diatur dalam Pasal 2 ayat (1) Peraturan Mahkamah Agung (Perma) Nomor 4 Tahun 2015 tentang Pedoman Beracara Dalam Penilaian Unsur Penyalahgunaan Wewenang, disebutkan bahwa PTUN berwenang untuk menerima, memeriksa dan memutus permohonan penilaian ada atau tidak ada penyalahgunaan wewenang dalam keputusan dan/atau tindakan Pejabat Pemerintahan sebelum dilakukan proses pidana Dalam ayat (2) lebih lanjut disebutkan bahwa PTUN baru berwenang menerima, memeriksa dan memutus permohonan penilaian setelah adanya hasil pengawasan APIP.

Badan dan/atau Pejabat Pemerintahan yang keberatan atas keputusan pejabat yang berwenang mengenakan Sanksi Administratif, maka Badan dan/atau Pejabat Pemerintah 
dapat mengajukan permohonan kepada PTUN untuk menguji apakah ada unsur penyalahgunaan wewenang dalam penetapan Keputusan dan/atau tindakan Pejabat tersebut. Apabila Pengadilan memutuskan tidak terdapat penyalahgunaan wewenang oleh PPK/PYB maka kerugian negara akan menjadi tanggungjawab Badan. Hal ini lah yang kemudian akan menjadi permasalahan baru mengenai bagaimana Badan akan memperoleh uang pengembalian kerugian negaranya.

PP Nomor 38 tahun 2016 dan Permendagri Nomor 133 Tahun 2018 sudah diatur tentang tata cara pegembalian kerugian negara/daerah oleh PNS Bukan Bendahara atau Pejabat Lain. Namun, dalam kedua peraturan tersebut tidak ditemukan aturan pelaksanaan pengembalian uang ke kas negara/daerah oleh Badan. Pembebanan tanggungjawab pengembalian kerugian negara/daerah yang dibebankan kepada Badan tentu saja menjadi hal yang percuma apabila sumber dananya berasal dari anggaran badan tersebut, artinya uang negara/daerah dipakai untuk mengembalikan kerugian negara/daerah.

Opsi lain yang biasanya dilakukan di lingkungan pemerintahan adalah PPK/PYB mengumpulkan dana secara kolektif dari seluruh pegawai di lingkungannya untuk mengembalikan kerugian negara/daerah. Namun, dengan mekanisme seperti ini tentu menjadi tidak adil bagi para pegawai yang tidak ada sangkut pautnya dengan keputusan PPK/PYB dalam penjatuhan hukuman disiplin PTDH tersebut.

Apakah pengembalian kerugian negara dapat dibebankan kepada PNS terpidana korupsi? Hal ini tentu saja akan sulit dilakukan karena kesalahan dilakukan oleh Pejabat/Badan. Pemerintah juga tidak memiliki kewenangan memaksa PNS yang sudah dipecat untuk mengembalikan gaji yang diterimanya selama menjalani hukuman penjara. APIP harus dapat membuktikan adanya penyalahgunaan wewenang atau pelanggaran terhadap aturan yang dilakukan oleh PPK/PYB sehingga tidak kalah dalam gugatan di PTUN. Putusan Hakim yang menguatkan adanya penyalahgunaan wewenang atau pelanggaran dalam proses penjatuhan hukuman disiplin diperlukan agar tanggungjawab pengembalian kerugian negara/daerah menjadi tanggungjawab individu PPK/PYB. Menuntut pengembalian kerugian negara kepada PPK/PYB akan lebih efektif untuk menutupi kerugian negaranya dan dapat menjadi efek jera bagi PPK/PYB lainnya.

Jika merujuk pada pandangan F.R. Bothlingk, maka Hakim PTUN akan sulit untuk menilai adanya kesalahan subyektif yang dilakukan PPK/PYB jika sebab terjadinya kesalahan subjektif itu merupakan tindakan amoral, itikad buruk, lalai, dan kecerobohan. Dalam hal ini hakim tidak cukup jika hanya menggunakan alat uji peraturan perundangundangan dan asas-asas umum pemerintahan yang baik. Dapat terjadi dua alat uji ini tidak mampu menjangkau atau membuktikan kesalahan subjektif tersebut. Artinya, hakim harus pula melibatkan hukum tidak tertulis, selain asas-asas umum pemerintahan yang baru. Sesudah melalui proses peradilan dan telah ada putusan (vonis) hakim yang berkekuatan hukum (rechtskrachtig) selanjutnya pelaksanaan tanggung jawab hukum itu berlangsung. ${ }^{21}$

APIP juga perlu meneliti lebih lanjut apakah tindakan PPK/PYB yang tidak memberhentikan PNS terpidana korupsi itu dapat dipertanggungjawabkan secara pidana dengan pertimbangan bahwa sanksi pidana akan memberikan efek jera yang lebih kuat kepada para PPK/PYB lainnya. Berdasarkan pasal 36 PP Nomor 48 Tahun 2016 disebutkan bahwa APIP harus melaporkan dan menyerahkan proses lebih lanjut kepada aparat penegak hukum dalam hal terjadi kerugian keuangan negara akibat tindakan

21 Anggara, Sahya. Op. Cit., h. 147-148. 
pejabat pemerintahan yang dilakukan bukan untuk melindungi kepentingan umum, dilakukan dengan itikad tidak baik, untuk memperkaya diri sendiri atau orang lain atau badan, dan ditemukan bukti adanya penyimpangan yang bersifat pidana.

Tujuan dalam pertanggungjawaban secara pidana ini bukan hanya sekedar untuk pemberian penderitaan dan efek jera kepada para PPK/PYB yang melakukan pelanggaran administratif, tapi juga agar menjadi semacam peringatan dari Pemerintah kepada para PPK/PYB dan seluruh ASN. Sanksi penjara sebagai penderitaan yang diberikan itu harus dipublikasikan secara luas, sehingga para pejabat, ASN dan masyarakat dapat melihat penderitaan itu sebagai wujud nyata dari keberadaan hukum di lingkungan pemerintahan yang benar benar ditegakkan.

Kebebasan diberikan kepada pejabat pemerintahan untuk melaksanakan kewenangan yang diberikan (discretionary power) namun tetap dengan batasan-batasan yang telah ditentukan untuk mencegah terjadinya penyalahgunaan wewenang. Hukum pidana juga memiliki kriteria yang digunakan untuk membatasi gerak pejabat pembuat kebijakan untuk terhindar dari unsur melawan hukum dan penyalahgunaan kewenangan. ${ }^{22}$ Pertentangan yang sering dibahas adalah apakah penyalahgunaan wewenang termasuk dalam ranah hukum administrasi dan pidana.

Romli Atmasasmita mengutip pandangan Oswald Jansen menyebutkan bahwa dalam referensi hasil penelitian mengenai keberadaan sanksi administrasi dan sanksi pidana di beberapa Negara Uni Eropa menunjukkan terdapat dua pandangan, yaitu pandangan yang mengakui keberadaan sanksi administrasi tidak mengesampingkan sanksi pidana atau disebut low degree of differentiation dan yang berpandangan bahwa keberadaan sanksi administrasi harus dipisahkan tegas dari sanksi pidana atau disebut high degree of differentiation. ${ }^{23}$ Berdasarkan pandangan terebut, Romli menyimpulkan bahwa sistem hukum di Indonesia mengakui hubungan erat antara sanksi administratif dan pidana karena keduanya dapat diterapkan secara paralel.

Pelaksanaan kebijakan atau kewenangan pertanggungjawaban dalam aspek pidana atau kriminalisasi baru dapat dilakukan apabila ternyata dalam pengambilan keputusan atau kebijakan itu ditemukan tindakan yang merupakan ranah hukum pidana, misalnya ditemukan adanya penyuapan, pemalsuan, dan lain-lain. ${ }^{24}$ Di negara-negara Eropa dan Amerika, persoalan menyalahgunakan kewenangan dan korupsi bukanlah pada pemahaman "kebijakan" tetapi lebih kepada persoalan hubungan antara kewenangan dengan bribery (penyuapan). Kewenangan pejabat publik yang berkaitan dengan kebijakan, baik yang terikat maupun yang aktif, tidak menjadi ranah hukum pidana sehingga kasus-kasus yang belakangan ini sering terjadi di Indonesia dan berkaitan penyalahgunaan kewenangan dan perbuatan melawan hukum menimbulkan kesan adanya suatu kriminalisasi kebijakan. ${ }^{25}$

22 Putradinata, Rizky, Serikat P. J., Nyoman \& Mulasari, Laila. (2016). Pertanggungjawaban Pidana Pejabat Pembuat Kebijakan (Policy Maker) Atas Diambilnya Kebijakan Yang Menimbulkan Kerugian Keuangan Negara. Diponegoro Law Journal, Volume 5, Nomor 3, h. 8.

23 Sarwo Rini, Nicken. (2018). Penyalahgunaan Kewenangan Administrasi Dalam Undang Undang Tindak Pidana Korupsi . Jurnal Penelitian Hukum De Jure, Vol.18 No. 2, Juni 2018, h. 268.

24 Simanjuntak, Enrico P. (2018). Pengujian Ada Tidaknya Penyalahgunaan Wewenang Menurut Undang-Undang Administrasi Pemerintahan. Jurnal Hukum dan Peradilan, Vol. 7 No. 2, Juli 2018, h. 244.

${ }^{25}$ Latif, Abdul. (2013), Tindakan Maladministrasi Dalam Pelayanan Publik dan Implikasinya Terhadap Korupsi. Jurnal Varia Peradilan No. 326 Januari 2013, h. 5 


\section{P E N U T U P}

Pemerintah pusat sebaiknya tidak hanya berusaha memberhentikan para PNS terpidana korupsi tapi juga patut untuk meminta pertanggungjawaban dari para Pejabat Pembina Kepegawaian/Pejabat Yang Berwenang yang selama ini tidak memberhentikan PNS terpidana korupsi. Perlu ada upaya pengembalian kerugian negara yang terjadi untuk menjaga akuntabilitas pemerintah pusat dan daerah sesuai dengan asas umum pemerintahan yang baik. Penjatuhan sanksi kepada para PPK/PYB juga perlu dilakukan untuk memberikan efek jera kepada para PPK/PYB lainnya. Pembebanan tanggung jawab hukum berupa sanksi administratif namun tidak menutup kemungkinan diterapkannya sanksi perdata dan pidana sebagai upaya terakhir untuk pemulihan kerugian keuangan negara

\section{DAFTAR PUSTAKA}

\section{Buku}

[1] Anggara, Sahya. (2018). Hukum Administrasi Negara. Bandung: Pustaka Setia.

[2] Gautama, Sudargo. (1973) Pengertian Negara Hukum, Bandung: Alumni.

[3] HR, Ridwan. (2006). Hukum Administrasi Negara. Jakarta: Rajawali Pers.

[4] Johan, Teuku Saiful Bahri. (2018). Hukum Tata Negara dan Hukum Administrasi Negara dalam Tataran Reformasi Ketatanegaraan Indonesia, Yogyakarta: Deepublish.

[5] Nurtjahjo, Hendra dkk. (2013). Memahami Maladministrasi. Jakarta: Ombudsman Republik Indonesia.

[6] Rapar, J. H. (1993). Filsafat Politik Aristoteles. Jakarta: Rajawali.

[7] Soekanto, Soerjono. (2008) Pengantar Penelitian Hukum, Jakarta: UI Press.

\section{Jurnal dan Lain-Lain}

[8] Bothlingk, F.R. (1954) Het Leerstuk der Vertegenwoordiging en Zijn Toepassing op Ambtsdragers in Nederland en in Indonesia, Juridische Boekhandel en Uitgeverrij A. Jongbloed \& Zoon's-Gravenhage.

[9] Komisi Aparatur Sipil Negara. (2019) 7 Alasan PPK belum melakukan PTDH Terhadap ASN Berstatus Terpidana Korupsi, diambil dari https://www.kasn.go.id/details/item/368-7-alasan-ppk-belum-melakukan-ptdhterhadap-asn-berstatus-terpidana-korupsi.

[10] Latif, Abdul. (2013), Tindakan Maladministrasi Dalam Pelayanan Publik dan Implikasinya Terhadap Korupsi. Jurnal Varia Peradilan No. 326 Januari 2013.

[11] Mokhsen, Nuraida, Dwiputrianti, Septiana \& Juniarto, Rifki. (2019), Pengawasan Penegakan Kode Etik dan Kode Perilaku Pegawai Aparatur Sipil Negara, Jurnal Komisi Aparatur Sipil Negara.

[12] Mustamu, Julista. (2014) Pertanggungjawaban Hukum Pemerintah (Kajian Tentang Ruang Lingkup Dan Hubungan Dengan Diskresi). SASI Vol. 20 No. 2 Juli - Desember 2014.

[13] Putradinata, Rizky, Serikat P. J., Nyoman \& Mulasari, Laila. (2016). Pertanggungjawaban Pidana Pejabat Pembuat Kebijakan (Policy Maker) Atas Diambilnya Kebijakan Yang Menimbulkan Kerugian Keuangan Negara. Diponegoro Law Journal, Volume 5, Nomor 3. 
[14] Rahmadhani, Fitri Muvariz (2019), Analisis Aspek Keadilan Dari Pemberhentian Tidak Dengan Hormat Sebagai Pegawai Negeri Sipil Di Indonesia, Jurnal Legislasi Indonesia Vol. 16 No.2 - Juni 2019.

[15] Sarwo Rini, Nicken. (2018). Penyalahgunaan Kewenangan Administrasi Dalam Undang Undang Tindak Pidana Korupsi . Jurnal Penelitian Hukum De Jure, Vol.18 No. 2, Juni 2018.

[16] Simanjuntak, Enrico P. (2018). Pengujian Ada Tidaknya Penyalahgunaan Wewenang Menurut Undang-Undang Administrasi Pemerintahan. Jurnal Hukum dan Peradilan, Volume 7 Nomor 2, Juli 2018.

[17] Sekretariat Kabinet. (2019). Penuntasan Capai 88\%, 1.906 PNS Terlibat Tipikor Diberhentikan Tidak Hormat. Diambil dari https://setkab.go.id/penuntasan-capai88-1-906-pns-terlibat-tipikor-diberhentikan-tidak- hormat/

[18] Sekretariat Kabinet. (2019). Keputusan Bersama Dirilis PNS Koruptor Akan Dipecat Desember 2018. Diambil dari https://irto.id/keputusan-bersama- dirilispns-koruptor-akan-dipecat-desember-2018-cZk1

[19] ICW. (2019) Berapa kerugian negara jika PNS korup belum dipecat. Diambil dari https://www.republika.co.id/berita/nasional/news-analysis/19/02/20/pn85q2430berapa-kerugian-negara-jika-pns-korup-belum-dipecat 